\title{
Comparison of pheromone traps against brinjal shoot and fruit borer, Leucinodes orbonalis (Lepidoptera: Crambidae)
}

\author{
R.F. Niranjana ${ }^{1 *}$, M. Devi ${ }^{2}$ and R. Philip Sridhar ${ }^{2}$ \\ ${ }^{1}$ Department of Agricultural Biology, Faculty of Agriculture, Eastern University Sri Lanka, \\ Chankalady \\ 2Department of Agricultural Entomology, Tamil Nadu Agricultural University, Coimbatore 641003, \\ Tamil Nadu, India
}

\begin{abstract}
The brinjal shoot and fruit borer, Leucinodes orbonalis is a destructive pest of brinjal and its control is difficult as the larvae inhabited inside the shoots or fruits of brinjal. Two different studies were conducted in farmer's field at Coimbatore, Tamil Nadu, India during Rabi 2013/14 (September, 2013 - January, 2014) and 2014/15 (September, 2014 - January, 2015) to evaluate the efficacy of 1) types of traps viz., sleeve and Wota-T traps, and erection heights viz., 30, 60, $90 \mathrm{~cm}$ above the crop canopy and at crop canopy level, and 2) concentration of lure viz., one, two and three mg (Lucin-lure $囚)$, and frequency of replacement of lure viz., 21, 45 and 60 days. The results showed that the Wota-T traps baited with $3 \mathrm{mg}$ lure concentration, replaced at every 21 days caught more number of male moths of L. orbonalis. Trap catch was significantly higher in pheromone traps placed in the same level of canopy.
\end{abstract}

Keywords: Leucinodes orbonalis, lure, pheromone traps, replacement frequency, traps erection height

\section{Introduction}

The brinjal shoot and fruit borer, Leucinodes orbonalis (Guenée) (Lepidoptera: Crambidae) is the most noxious and destructive pest of brinjal and widely distributed in South Asian countries (Talekar, 2002). The yield loss up to $60-80 \%$ (Krishnaiah and Vijay, 1975; Kaur et al., 2010) was recorded in brinjal cultivation by the infestation of $L$. orbonalis. The management of this pest is difficult as its larvae inhabit inside the plant's shoots or fruits by forming tunnels (Alam et al., 2003) and the pesticide do not reach the pest directly. The control of $L$. orbonalis is fairly possible when the spraying of pesticides was occurred before the neonate larvae bore inside shoots or fruits; once in the shoots or fruits, larvae are inaccessible to the killing action of surface applied chemicals. Since neonate larvae can enter fruits or shoots within only a few hours of hatching from eggs, pesticides have to be applied frequently in order to have sufficient toxic residues on the plant surface adequate enough to kill the crawling larvae (Alam et al., 2003). Besides, the frequent application of insecticides is not advisable when the crops are in fruiting stage.

Though, farmers rely exclusively on the application of pesticides to control $L$. orbonalis, produce blemish-free brinjal fruits and get maximum yield (Srinivasan, 2008). Excessive use of chemical pesticides in brinjal cultivation enhances the accumulation of residues in brinjal fruits, thereby threatens the human health and environment (Srinivasan, 2008). Thus the present trend of pest management moves towards the development of eco-friendly management practices through Integrated

Received 28 March 2017. Accepted 19 July 2017. * Corresponding author: nirurodney@gmail.com 
Pest Management (IPM). The integration of pheromone trap as an effective component of IPM program (Gunawardena and Attygalle, 1989; Cork et al., 2001; Chatterjee, 2009; Mazumder and Khalequzzaman, 2010) in monitoring pest population for early decision making, and also mass trapping of pests using lures baited with a killing agent. Based on the moth catches in pheromone trap it is easy to recognize the prevailing life stages of brinjal shoot and fruit borer at the brinjal cultivation on a particular time and which will direct to select the proper management practices against brinjal shoot and fruit borer. Therefore, the study on comparison of pheromone traps of brinjal shoot and fruit borer will help to select proper pheromone trap with suitable erection height and lure replacement interval which findings reduce the indiscriminate use of insecticides in brinjal cultivation against brinjal shoot and fruit borer, L. orbonalis.

\section{Materials and Methods}

Trap type and erection height in relation to crop canopy

A field experiment was conducted in a farmer's field at Coimbatore, Tamil Nadu, India for assessing the types of traps viz., sleeve and Wota-T traps (Fig. 1) and erection heights viz., 30, 60, $90 \mathrm{~cm}$ above the crop canopy and at crop canopy level during Rabi, 2013/14 (September, 2013 January, 2014) with an air temperature $27 \pm 5{ }^{\circ} \mathrm{C}$ and Relative Humidity $70 \pm 5 \%$.

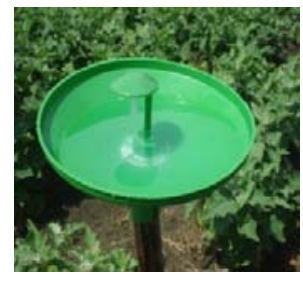

1.a) Wota-T

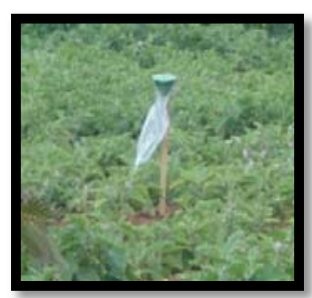

1.b) Sleeve trap
Fig.1 Types of traps
The sex pheromone of L. orbonalis, a mixture of (E)-11-hexadecenyl acetate and (E)-11-hexadecen-1-ol) showed promising effect (Zhu et al., 1987; Attygale et al., 1988; Cork et al., 2001) against the moths of $L$. orbonalis. The commercialized sex pheromone of $L$. orbonalsi with similar properties were purchased at Pest Control of India, New Delhi, India and used for the study.

The Wota-T traps which consisted a hood to hold pheromone lure and a tray where soapy water was kept whereas the sleeve trap had a hood to place pheromone lure and sleeve made by polyethylene to collect caught moths. Both traps were purchased at Pest Control of India, New Delhi, India.

The traps were installed 30 days after transplanting of brinjal at different heights viz., 30, 60, $90 \mathrm{~cm}$ above the crop canopy and at crop canopy level with an inter trap distance of $20 \mathrm{~m}$. The traps were fixed on bamboo poles and two mg of lure (Lucinlure $\left.{ }^{\circledR}\right)$ were used. The lures were fixed on the lower side of the hood. The experiment was laid out in Randomized Block Design with 8 treatments, and each treatment was replicated thrice.

Pheromone lures concentration and interval of lure replacement

Field experiment was carried out in a farmer's field at Coimbatore, Tamil Nadu, India during Rabi, 2014/15 (September, 2014 - January, 2015) to find out the effect of concentration viz., One, two and three mg lures (Lucin-lure ${ }^{\circledR}$ ) and frequency of replacement of lure viz., 21, 45 and 60 days. The experiment was laid out in RBD with 9 treatments and each treatment replicated thrice.

The frequency of replacement of lure (Lucin-lure ${ }^{\circledR}$ ) has been mentioned in the label of its commercial product as 2 months (60 days). In general, it was assumed from the previous studies that 
the lure can be effective for about 21 days and it is climate dependent. Therefore, the study has been designed to check the suitability of recommended frequency of replacement of lure to the study area.

\section{Data analysis}

Observations on moth catches were recorded at weekly intervals, and monthly averages were calculated to evaluate the efficacy of each treatment using two-way ANOVA.

\section{Results and Discussion}

\section{Trap type and erection height}

Mean number of moths captured in two types of traps at different heights is presented in Table 1 \& Fig. 2. The numbers of moths captured in Wota-T traps were significantly greater than the sleeve traps. The moth catches ranged from 3.08 to 9.33 in sleeve trap, while it was 7.08 to 23.50 in Wota-T traps at different heights (Fig. 3).

Among the heights tested, height at crop canopy level proved to be the most optimum in Wota-T traps (23.50 moth catches/trap) as well as sleeve traps (9.33 moth catches/trap). The lowest moth catches were observed in $90 \mathrm{~cm}$ above the canopy level (7.08 and 3.08 moth catches/trap in Wota-T traps and sleeve traps, respectively).

Cork et al., (2003) stated that open delta trap caught significantly greater numbers of L. orbonalis males than other traps tested by them at the canopy level (delta, open delta, water with plastic bottle and sleeve trap). However, the authors revealed that open traps with water were more efficient in trapping adult male moths as water prevents the moths from escaping. Apart from these, Nandihalli et al., (1991); and Raj et al., (2000) suggested that sleeve and funnel traps were superior in catching Helicoverpa armigera. Similarly, Mohan Naik et al., (1993) noticed that sleeve and ICRISAT funnel traps were found better than sticky traps in catching Helicoverpa armigera.

Although there were few references (Andagopal et al., 2010) to prove the efficacy of Wota-T trap, Cork et al., (2003) mentioned that the open trap with water performed better in capturing the $L$. orbonalis moths. The Wota-T trap was an open typed trap and contained water hence the findings of present study could be evidenced by the study of Cork et al., (2003) and Andagopal et al., 2010.

\section{Pheromone lures concentration and changing interval}

The data (Table 2 \& Fig. 4) on lure concentration and changing frequency showed that three mg septum replaced every 21 days was the most effective (39.87 moths/trap) followed by two mg septum replaced every 21 days (29.19 moths/trap) and three $\mathrm{mg}$ septum replaced every 45 days (27.34 moths/trap). The least trap catches were recorded in one $\mathrm{mg}$ septum replaced every 60 days (14.07 moths/trap).

Sateeshkumar et al., (2009) stated that a dose of $2 \mathrm{mg}$ per dispenser is considered sufficient for the purpose of monitoring the pest incidence of L. orbonalis and also cost effectiveness. The trap catches were highest in those traps with lures changed every 21 days, while changes made every $45^{\text {th }}$ and $60^{\text {th }}$ day were also promising but only up to 21 days and thereafter declined gradually indicating that irrespective of the changing frequency, the test lures were found to be effective up to 21 days. These results are in conformity with those of Lalitha Kumari and Reddy (1992); Patil and Mamadapur (1996); Loganathan et al., changed in three weeks. (1999) who 
reported that lures must be changed in three weeks.

Table 1. Effect of pheromone trap types and erection height on L. orbonalis moth catches

\begin{tabular}{|c|c|c|}
\hline Types of pheromone traps & Erection height & $\begin{array}{l}\text { Overall mean moth } \\
\text { catch/trap* }\end{array}$ \\
\hline \multirow{4}{*}{ Sleeve trap } & $30 \mathrm{~cm}$ above canopy level & $7.58^{\mathrm{cd}}$ \\
\hline & $60 \mathrm{~cm}$ above canopy level & $\begin{array}{l}5.92 \mathrm{e} \\
(2.53)\end{array}$ \\
\hline & $90 \mathrm{~cm}$ above canopy level & $\begin{array}{l}3.08^{f} \\
(1.89)\end{array}$ \\
\hline & canopy level & $\begin{array}{l}9.33^{c} \\
(3.14)\end{array}$ \\
\hline \multirow[t]{4}{*}{ Wota-T trap } & $30 \mathrm{~cm}$ above canopy level & $\begin{array}{l}22.08^{a} \\
(4.75)\end{array}$ \\
\hline & $60 \mathrm{~cm}$ above canopy level & $\begin{array}{l}12.42^{b} \\
(3.59)\end{array}$ \\
\hline & $90 \mathrm{~cm}$ above canopy level & $\begin{array}{l}7.08 \mathrm{de} \\
(2.75)\end{array}$ \\
\hline & canopy level & $\begin{array}{l}23.50^{\mathrm{a}} \\
(4.90)\end{array}$ \\
\hline \multirow[t]{3}{*}{ SEd } & Types of pheromone traps & 0.08 \\
\hline & Erection height & 0.11 \\
\hline & Interaction & 0.15 \\
\hline \multirow{3}{*}{ CD (0.05) } & Types of pheromone traps & 0.16 \\
\hline & Erection height & 0.23 \\
\hline & Interaction & 0.32 \\
\hline
\end{tabular}

*Values are mean of three replications.

Values in parentheses are based on square root $(\sqrt{ }(X+0.5))$ transformation.

In column, means with similar alphabets do not vary significantly at $\mathrm{P}=0.05$ by DMRT.

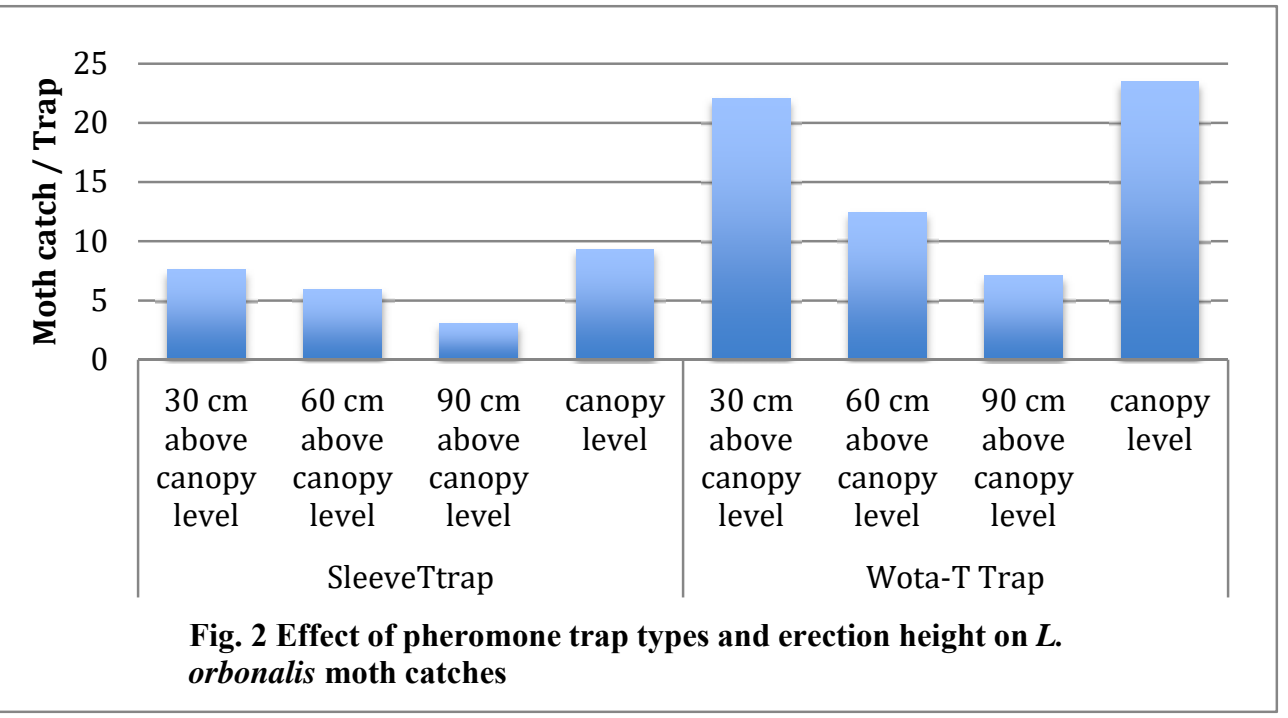






Fig. 3. Moth catches in Wota-T trap

Table 2. Effect of concentration and replacement interval of pheromone lure on moth catches of L. orbonalis

\begin{tabular}{|c|c|c|}
\hline Replacement interval & Concentration & $\begin{array}{l}\text { Overall mean moth } \\
\text { catch/trap* }\end{array}$ \\
\hline \multirow[t]{3}{*}{21 days } & $1 \mathrm{mg}$ septum & $\begin{array}{c}20.97^{\mathrm{cd}} \\
(4.63)\end{array}$ \\
\hline & $2 \mathrm{mg}$ septum & $\begin{array}{l}29.19 \mathrm{~b} \\
(5.45)\end{array}$ \\
\hline & $3 \mathrm{mg}$ septum & $\begin{array}{l}39.87 a \\
(6.35)\end{array}$ \\
\hline \multirow[t]{3}{*}{45 days } & $1 \mathrm{mg}$ septum & $\begin{array}{l}17.71^{\mathrm{e}} \\
(4.27)\end{array}$ \\
\hline & $2 \mathrm{mg}$ septum & $\begin{array}{l}21.21^{\mathrm{cd}} \\
(4.66)\end{array}$ \\
\hline & $3 \mathrm{mg}$ septum & $\begin{array}{l}27.34^{\mathrm{b}} \\
(5.28)\end{array}$ \\
\hline \multirow[t]{3}{*}{60 days } & $1 \mathrm{mg}$ septum & $\begin{array}{l}14.07^{\mathrm{f}} \\
(3.82)\end{array}$ \\
\hline & $2 \mathrm{mg}$ septum & $\begin{array}{l}20.27 \mathrm{~d} \\
(4.56)\end{array}$ \\
\hline & $3 \mathrm{mg}$ septum & $\begin{array}{l}22.68^{c} \\
(4.81)\end{array}$ \\
\hline \multirow[t]{3}{*}{ SEd } & Replacement interval & 0.07 \\
\hline & Concentration & 0.07 \\
\hline & Interaction & 0.11 \\
\hline \multirow[t]{3}{*}{$\mathrm{CD}(0.05)$} & Replacement interval & 0.14 \\
\hline & Concentration & 0.14 \\
\hline & Interaction & 0.24 \\
\hline
\end{tabular}




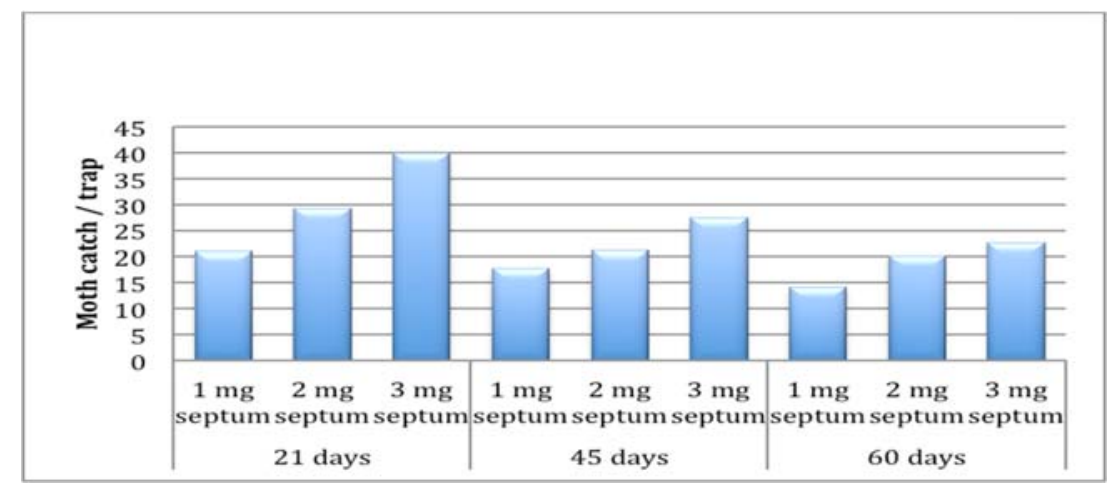

Fig. 4. Effect of concentration and replacement interval of pheromone lure on moth catches of L. orbonalis

\section{Conclusion}

It can be concluded from the study that the Wota-T trap was the most suitable trap to catch the more number of adult moths of Leucinodes orbonalis than the sleeve trap. Further the study revealed that to install the pheromone trap at the canopy level was most appropriate height.

In addition, the study stated the superiority of $3 \mathrm{mg}$ concentration of lures of sex pheromone of $L$. orbonalis in catching the maximum adult moths of $L$. orbonalis. Among the tested replacement intervals of pheromone lure 21 days gave better results with more adult moth catches.

\section{References}

Alam, S. N., Rashid, M. A., Rouf, F. M. A., Jhala, R. C., Patel, J. R., Satpathy, S., Shivalingaswamy, T. M., Rai, S., Wahundeniya, I., Cork, A., Ammaranan, C. and Talekar, N. S. (2003). Development of an integrated pest management strategy for eggplant fruit and shoot borer in South Asia. Shanhua, Taiwan: AVRDC - the World Vegetable Center. Technical Bulletin No. 28. AVRDC Publication No. 03-548. 56 pp.

Andagopal, V.N., Prasad T.V., Jethwa Dha rmrajsinh, Gedia M.V., Koradia V.G., Patel H.V. (2010). Evaluation of pheromone traps against brinjal fruit and shoot borer, Leucinodes orbonalis Guenee. Indian Journal of Entomology 72(1): 7 - 10.

Attygale, A. B., J. Schwarz and N. E. Gunawardena. (1988). Sex pheromone of brinjal shoot and fruit borer Leucinodes orbonalis Guenee (Lepidoptera: Pyrallidae). Zeitschrift für Naturforschung 43: 790-792.

Chatterjee, H. (2009). Pheromones for the management of brinjal fruit and shoot borer, Leucinodes orbonalis Guenee. Karnataka Journal of Agriculture Science 22: 594-596.

Cork, A., Alam, S. N., Rouf, F. M. A. and Talekar, N. S. (2003). Female sex pheromone of brinjal shoot and fruit borer Leucinodes orbonalis: Trap optimization and application in IPM trials. Bulletin of Entomological Research 93: 107-113.

Cork, A., S. N. Alam, A. Das, C. S. Das, G. C. Ghosh, S. Phythian, D. I. Farman, D. R. Hall, N. R. Masten, K. Vedham, F. M. A. Rouf and K. Srinivasan. (2001). Female sex pheromone of brinjal shoot and fruit borer Leucinodes orbonalis (Lepidoptera: Pyrallidae): Blend optimization. Journal of Chemical Ecology 27: 1867-1877.

Gunawardena, N. E. and Attygalle, A. B. (1989). The sex pheromone of the brinjal pest, Leucinodes orbonalis Guenee 
(Lepidoptera): Problems and Perspectives. Journal of National Science Council of Sri Lanka 17(2): 161 - 171.

Kaur, M., S. Dhatt, S. Ajmer, J. Sandhu and S. Gosal Satbir. (2010). Genetic transformation of Cry 1AC gene to counter fruit and shoot borer of brinjal (Solanum melongena L). Crop Improvement 37(2): 200.

Krishnaiah, K. and O. P. Vijay. (1975). Evaluation of Brinjal varieties for resistance to shoot and fruit borer Leucinodes orbonalis Guen. Indian Journal of Horticulture 32: 84-86.

Lalitha Kumari, V. L. and Reddy, D. D. R. (1992). Evaluation of pheromone trap designs for trapping Spodoptera litura and Helicoverpa armigera and their reproductive behavior. Indian Journal of Plant Protection 20: 18-23.

Loganathan, M., Sasikumar, M. and Uthamaswamy, S. (1999). Assessment of duration of pheromone dispersion for monitoring Helicoverpa armigera (H.) on cotton. Journal of Entomological Reseach 23(1): 61-64.

Mazumder, $\mathrm{F}$ and Khalequzzaman, $\mathrm{M}$. (2010). Eggplant shoot and fruit borer Leucinodes orbonalis guénee male moth catch in sex pheromone trap with special reference of lure elevation and IPM. Journal of bio-science 18: 9-15.

Mohan Naik, Lingappa, B. and Patil, B. V. (1993). A note on the efficiency of different pheromone traps in monitoring Helicoverpa armigera (Hubner) males. Karnataka Journal of Agricultural Sciences 6(1): 64-66.
Nandihalli, B. S., Huger, P. and Patil, B. V. (1991). Efficacy of three types of pheromone traps in trapping Heliothis armigera Hub. Madras Agriculture Journal 78(1-4): 91-92.

Patil, B. V. and Mamadapur, B. B. (1996). Performance of some sex pheromone traps and lures of Helicoverpa armigera (H.). Indian Journal of Plant Protection 24 (1\&2): 128-129.

Raj, H. S., M. P. Gupta and M. L. Verma. (2000). Comparative effectiveness of traps for trapping male moths of Helicoverpa armigera. Annals of Plant Protection Sciences 8(2): 235-236.

Sateeshkumar, J. V., Koteswara Rao, S. R. and Rahman, S. J. (2009). Effect of certain factors on pheromone trap moth catches of brinjal shoot and fruit borer, Leucinodes orbonalis Guenee. Indian Journal of Entomology 71(4): 317-319.

Srinivasan, R. (2008). Integrated Pest Management for eggplant fruit and shoot borer (Leucinodes orbonalis) in South and Southeast Asia: Past, Present and Future. Journal of Biopesticides 1(2): 105-112.

Talekar, N. S. (2002). Controlling eggplant shoot and fruit borer: A simple, safe and economical approach. International Cooperators' Guide, Publication No. \#02534, Shanhua, Taiwan: Asian Vegetable Research and Development, Center.

Zhu, P., F. Kong, S. Yu, S. Jin, X. Hu and J. Xu. (1987). Identification of the sex pheromone of eggplant borer, Leucinodes orbonalis Guenee (Lepidoptera: Pyralidae). Zeitschrift für Naturforschung 42: 1347-1348. 